\title{
The role of neuraminidase in haemagglutination and adherence to colon WiDr cells by Bacteroides fragilis
}

\author{
F. NAMAVAR, M. W. VAN DER BIJL, B. J. APPELMELK, J. DE GRAAFF and D. M. MACLAREN
}

Department of Medical Microbiology, Medical School, Vrije Universiteit, Van der Boechorststraat 7 , 1081 BT Amsterdam, The Netherlands

\begin{abstract}
Summary. The role of neuraminidase in haemagglutination and adherence to colon WiDr cells by eight strains of Bacteroides fragilis and four strains of oral black-pigmented gramnegative anaerobes was studied. Neuraminidase treatment resulted in a very small increase of haemagglutination by some of the strains but had no effect on adherence to WiDr cells by all bacterial strains tested except one strain of Prevotella intermedia (HG 110). Inhibition of neuraminidase had no effect on haemagglutination or adherence, nor was any correlation found between haemagglutinating ability and neuraminidase activity in the $B$. fragilis strain. The results indicated that haemagglutination and adherence of $B$. fragilis to WiDr cells were not mediated by neuraminidase.
\end{abstract}

\section{Introduction}

Bacteroides fragilis is a normal inhabitant of the human alimentary tract and plays an important role in infections. ${ }^{1-3}$ Neuraminidase (NA), which is found in various pathogenic bacteria, has been thought to contribute to the pathogenicity of $B$. fragilis. ${ }^{4-7}$ Bacterial adherence to cell surfaces may involve lectin-like sites on the surface of micro-organisms that bind to specific ligands on the mammalian cells. Neuraminidase specifically cleaves $\mathrm{N}$-acetylneuraminic acid (NANA) from the cell membrane and exposes $\beta$ galactosyl determinants which may function as ligands. ${ }^{8}$ Okuda et al. ${ }^{9}$ have found that Prevotella intermedia HG 110 does not agglutinate erythrocytes; however, NA treatment of erythrocytes resulted in strong agglutination by $P r$. intermedia. Guzman et $a l .{ }^{10}$ have suggested a possible role for NA of $B$. fragilis in adherence to both erythrocytes and epithelial cells. The purpose of this study was to investigate the influence of NA on adherence to WiDr cells derived from the colon and on haemagglutination (HA) by strains of $B$. fragilis, Pr. intermedia and Porphyromonas gingivalis.

\section{Materials and methods}

\section{Bacterial strains}

Pr. intermedia (formerly $B$. intermedius) strains HG 189 and HG 653 were isolated from patients with periodontitis; Pr. intermedia strain HG 110 (ATCC
25611) and $P$. gingivalis (formerly $B$. gingivalis) strain HG 372 (ATCC 33277) were obtained from the American Type Culture Collection. B. fragilis strains were isolated from clinical specimens at the Academic Hospital of the Vrije Universiteit, Amsterdam. ${ }^{11}$ All

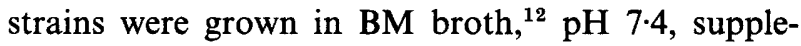
mented with haemin (BDH) $5 \mathrm{mg} / \mathrm{L}$ and menadione (Merck) $2 \mathrm{mg} / \mathrm{L}$ at $37^{\circ} \mathrm{C}$ in an anaerobic chamber (Coy's Manufacturing Co., USA) with an atmosphere of $\mathrm{N}_{2} 80 \%, \mathrm{H}_{2} 10 \%$ and $\mathrm{CO}_{2} 10 \%$ for $48 \mathrm{~h}$.

\section{Haemagglutination $(H A)$ test}

Chicken red blood cells (RBC) were washed three times with phosphate-buffered saline (PBS, $\mathrm{pH} 7 \cdot 4$ ) and suspended in PBS to give a concentration of $2 \%$ $\mathrm{v} / \mathrm{v}$. Bacterial cells were grown for $48 \mathrm{~h}$, washed three times, then suspended in PBS to a concentration of $2.5 \times 10^{9} \mathrm{cfu} / \mathrm{ml}$, as estimated by optical density. Serial two-fold dilutions of the bacterial suspensions were made in $50 \mu 1$ volumes of PBS in a round-bottomed microtitration plate and $50 \mu \mathrm{l}$ of $\mathrm{RBC}$ suspension were added to each well. The plate was shaken gently for $1 \mathrm{~h}$ and held overnight at $4^{\circ} \mathrm{C}$. The HA titre was expressed as the highest dilution of bacteria that showed HA activity. Peanut lectin (PNA) from Arachis hypogaea (Sigma) at a concentration of $16 \mu \mathrm{g} / \mathrm{ml}$ was used as a positive control.

\section{Adherence to WiDr cells}

A monolayer of WiDr cells (ATCC; CCL 218) was prepared in a $50-\mathrm{ml}$ tissue-culture flask (Costar). The cells were seeded at $5 \times 10^{6}$ cells/flask in DMEM

Received 14 Sept. 1993; revised version accepted 8 Dec. 1993. 
(Falcon Laboratories) supplemented with fetal bovine serum (Gibco) $20 \%$, penicillin $100 \mathrm{U} / \mathrm{ml}$ and streptomycin $100 \mu \mathrm{g} / \mathrm{ml}$ (Falcon Laboratories) and incubated at $37^{\circ} \mathrm{C}$ in air with $\mathrm{CO}_{2} 10 \%$ for $72 \mathrm{~h}$. The cells were washed with PBS and resuspended in $1 \mathrm{ml}$ of DMEM with serum and without antibiotics; $35 \mu \mathrm{l}$ were then immobilised on a glass coverslip (diameter $15 \mathrm{~mm}$ ) in a 24-multiwell flat-bottomed tissue-culture plate and incubated overnight at $37^{\circ} \mathrm{C}$. Non-adherent cells were washed off and $50 \mu \mathrm{l}$ of bacterial suspension in PBS $\left(5 \times 10^{8} \mathrm{cfu} / \mathrm{ml}\right)$ and $0.5 \mathrm{ml}$ of DMEM without antibiotics were added to the coverslip and incubated at $37^{\circ} \mathrm{C}$ for $1 \mathrm{~h}$. The cells were then washed with PBS, fixed with acetone, stained with fuchsin and examined by light microscopy at a magnification of $\times 1000$. The numbers of bacterial cells adhering to each of $50 \mathrm{WiDr}$ cells were counted in duplicate. Adhesion was expressed as the mean number of adherent bacteria/cell.

\section{Enzyme and enzyme inhibitor}

The enzyme NA from Vibrio cholerae and the NAinhibitor, ${ }^{13}$ 2-deoxy-2,3-dehydro-N-acetylneuraminic acid (Boehringer Mannheim) were used at concentrations of $0.05 \mathrm{U} / \mathrm{ml}$ and $10 \mathrm{mmol} / \mathrm{ml}$ respectively. These were the highest concentrations that did not cause lysis of the RBC after incubation at $37^{\circ} \mathrm{C}$ for $1 \mathrm{~h}$. Treatment with NA or NA-inhibitor, or both, was performed with the RBC $10 \%$ suspension and the WiDr cells $\left(5 \times 10^{6}\right)$ at $37^{\circ} \mathrm{C}$ for $1 \mathrm{~h}$. The cells were washed three times with PBS and the concentration of RBC was adjusted to $2 \%$ in PBS. WiDr cells were suspended in PBS to the original volume. Samples containing RBC or WiDr cells without NA or NAinhibitor were also prepared and used as controls. Bacterial cells $\left(2.5 \times 10^{9} \mathrm{cfu} / \mathrm{ml}\right)$ were also treated with either NA or NA-inhibitor and with both, washed three times then resuspended in PBS to the original volume, before testing for $\mathrm{HA}$ and adherence to WiDr cells.

\section{Detection of NA in bacterial cell extract}

Bacterial cells were grown in BM broth for $48 \mathrm{~h}$, washed three times in PBS and suspended in PBS to a concentration of $5 \times 10^{8} \mathrm{cfu} / \mathrm{ml}$. The washed cells were disrupted for $3 \mathrm{~min}$ with an MSE $150 \mathrm{~W}$ ultrasonic disintegrator.

Fetuin (Sigma) at a concentration of $5 \mathrm{mg} / \mathrm{ml}$ was used as substrate; $0.2 \mathrm{ml}$ of bacterial cell extract was added to $0.2 \mathrm{ml}$ of substrate and incubated at $37^{\circ} \mathrm{C}$ for $18 \mathrm{~h}$. Inhibition of enzyme activity was investigated by adding $0 \cdot 1 \mathrm{ml}$ of different concentrations of 2-deoxy2,3-dehydro- $\mathrm{N}$-acetylneuraminic acid and incubating at $37^{\circ} \mathrm{C}$ for $18 \mathrm{~h}$. The reaction was stopped by the addition of $0.1 \mathrm{ml}$ of $0.2 \mathrm{M}$ sodium metaperiodate in $9 \mathrm{M} o$-phosphoric acid to $0.1 \mathrm{ml}$ of cell extract and substrate. The enzymatically released NANA was measured in a Gilford spectrophotometer as described previously. ${ }^{11}$

\section{Results}

Effect of $N A$ and $N A$-inhibitor treatment of $R B C$ on $H A$ by bacterial strains

The effect of pre-treatment of RBC with NA, NAinhibitor and with both, on the ability of bacterial strains to cause HA is shown in table I. Untreated RBC failed to aggregate when exposed to PNA, but after treatment with NA, agglutination took place. NA-inhibitor prevented agglutination of NA-treated RBC by PNA, which confirms that 2-deoxy-2,3-Nacetylneuraminic acid inhibits the activity of NA from $V$. cholerae. All strains apart from those of Pr. intermedia agglutinated untreated $\mathrm{RBC}$ to varying degrees; NA treatment of RBC did not lead noticeably to improved HA except with Pr. intermedia HG 110. B. fragilis strains BE 12, BE 49 and BE 61, Pr.

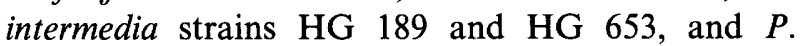
gingivalis strain HG 372 showed a two-fold increase in HA when RBC treated with NA were used. Pr. intermedia HG 110 showed a 32 -fold increase in HA activity with NA-treated RBC. Unfortunately, this strain was auto-agglutinable and its adherence to WiDr cells could not be measured accurately. Treatment of RBC with NA, either with or without NAinhibitor, did not affect HA when compared to controls (untreated RBC). B. fragilis $\mathrm{BE} 17$ showed no $\mathrm{HA}$ activity with the bacterial concentrations used in this study but had a high NA activity $(32.8 \mathrm{nmol} /$ $\min / 10^{8} \mathrm{cfu}$ ). On the other hand, $B$. fragilis BE61 showed a higher HA titre (32) but low NA activity $\left(20.0 \mathrm{mmol} / \mathrm{min} / 10^{8} \mathrm{cfu}\right)$. These results suggest strongly that there is no correlation between $\mathrm{HA}$ and NA activity in $B$. fragilis strains. Treatment of bacterial strains with NA, its inhibitor, and with both, did not change the HA patterns when compared to the untreated group.

\section{Effect of treatment of WiDr cells with NA and NA- inhibitor on the adherence of bacterial cells}

The effect of pre-treatment of WiDr cells with NA and NA-inhibitor on the subsequent adherence of bacterial cells is shown in table II. Bacterial strains varied in their ability to adhere to WiDr cells; $B$. fragilis $\mathrm{BE} 17$, which did not agglutinate $\mathrm{RBC}$, adhered in small numbers to WiDr cells whereas $B$. fragilis $\mathrm{BE}$ 61, which had a high HA titre, had the highest number of bacteria attached per WiDr cell. However, no relationship was found between HA and adherence to WiDr cells in the other bacterial species and strains. The treatment of WiDr cells with NA or NA-inhibitor did not affect adherence when compared to untreated cells. The treatment of bacterial strains with NA, its inhibitor and with both, did not affect adherence when compared to untreated bacteria. 
Table I. HA titres and NA activity of bacterial strains and peanut lectin (PNA) with RBC treated with NA and NA-inhibitor (NI)

\begin{tabular}{|c|c|c|c|c|c|}
\hline \multirow{3}{*}{$\begin{array}{l}\text { Bacterial } \\
\text { strains }\end{array}$} & \multicolumn{4}{|c|}{ HA titres with $\mathrm{RBC}$ that were } & \multirow{3}{*}{$\begin{array}{c}\text { Mean (SD) } \\
\text { NA activity } \\
(\mathrm{nmol} / \mathrm{min} / \\
\left.10^{8} \mathrm{cfu}\right)^{*}\end{array}$} \\
\hline & \multirow{2}{*}{ untreated } & \multicolumn{3}{|c|}{ pre-treated with } & \\
\hline & & NA & $\mathrm{NA}+\mathrm{NI}$ & $\mathrm{NI}$ & \\
\hline PNA & $0 \dagger$ & 64 & 0 & 0 & - \\
\hline \multicolumn{6}{|l|}{ B. fragilis } \\
\hline BE 1 & 16 & 16 & 16 & 16 & $19 \cdot 0(2 \cdot 2)$ \\
\hline BE 2 & 8 & 8 & 8 & 8 & $34 \cdot 0(3 \cdot 5)$ \\
\hline BE 4 & 32 & 32 & 32 & 32 & $22 \cdot 0(3 \cdot 2)$ \\
\hline BE 12 & 8 & 16 & 8 & 8 & $36 \cdot 6(5 \cdot 6)$ \\
\hline BE 17 & $0 \ddagger$ & 0 & 0 & 0 & $32 \cdot 8(5 \cdot 6)$ \\
\hline BE 43 & 32 & 32 & 32 & 32 & $30 \cdot 2(4 \cdot 3)$ \\
\hline BE 49 & 16 & 32 & 16 & 16 & $18 \cdot 0(4 \cdot 7)$ \\
\hline BE 61 & 32 & 64 & 32 & 32 & $20 \cdot 0(4 \cdot 1)$ \\
\hline \multicolumn{6}{|c|}{ Pr. intermedia } \\
\hline HG 189 & 0 & 2 & 2 & 2 & ND \\
\hline HG 653 & 0 & 2 & 2 & 2 & ND \\
\hline HG 110 & 0 & 32 & 2 & 2 & ND \\
\hline \multicolumn{6}{|l|}{ P. gingivalis } \\
\hline HG 372 & 2048 & 4096 & 2048 & 2048 & ND \\
\hline
\end{tabular}

ND, not done.

* All values calculated are the mean (SD) of three experiments.

$\uparrow$ No agglutination with $16 \mu \mathrm{g} / \mathrm{ml}$ lectin.

No agglutination with $1.2 \times 10^{9} \mathrm{cfu} / \mathrm{ml}$.

Table II. Adherence of bacterial cells to WiDr cells treated with NA and NA-inhibitor (NI)

\begin{tabular}{cccc}
\hline & \multicolumn{3}{c}{ Adherence to WiDr celis* that were } \\
\cline { 3 - 4 } Bacterial \\
strains & & \multicolumn{2}{c}{ treated with } \\
\cline { 3 - 4 } & untreated & NA & NI \\
\hline & & & \\
B. fragilis & & & \\
BE 1 & $1.7(0.10)$ & $1.6(0.21)$ & $1.8(0.20)$ \\
BE 2 & $2.2(0.11)$ & $1.8(0.20)$ & $2.0(0.19)$ \\
BE 4 & $1.5(0.08)$ & $1.7(0.10)$ & $2.0(0.06)$ \\
BE 12 & $3.3(0.14)$ & $3.0(0.57)$ & $2.4(0.10)$ \\
BE 17 & $0.4(0.06)$ & $0.3(0.04)$ & $0.4(0.10)$ \\
BE 43 & $2.4(0.21)$ & $2.4(0.17)$ & $3.2(0.35)$ \\
BE 49 & $3.3(0.42)$ & $2.9(0.42)$ & $3.4(0.40)$ \\
BE 61 & $4.5(0.71)$ & $4.6(0.35)$ & $4.6(0.51)$ \\
$P$. intermedia & & & \\
HG 189 & $0.7(0.40)$ & $0.6(0.35)$ & $0.7(0.41)$ \\
HG 653 & $0.6(0.40)$ & $0.6(0.30)$ & $0.7(0.35)$ \\
$P$. gingivalis & & & \\
HG 372 & $1.2(0.50)$ & $1.6(0.41)$ & $1.0(0.48)$ \\
\hline
\end{tabular}

* All values are the mean (SD) of three experiments; each value represents the number of attached bacteria/cell.

\section{Effect of $N A$-inhibitor on $N A$ activity of $B$. fragilis}

To investigate whether 2-deoxy-2,3-dehydro-Nacetylneuraminic acid could act as a competitive inhibitor of $B$. fragilis neuraminidase activity, different concentrations of NA inhibitor were tested on the NA activity of bacterial cell extract (figure). NA inhibitor at a concentration of $10 \mathrm{mmol} / \mathrm{ml}$ inhibited NA activity of $B$. fragilis BE 61 by $85 \%$. These results showed that NA activity of $B$. fragilis is inhibited by the NA-inhibitor.

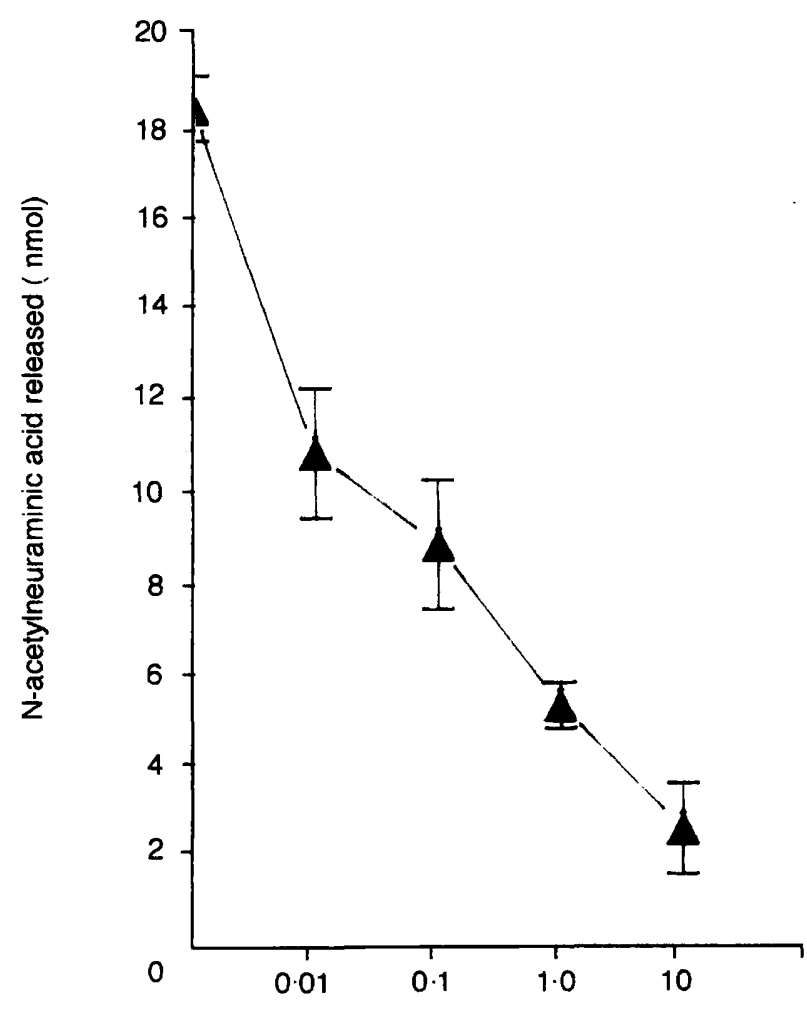

Concentration of inhibitor $(\mathrm{mmol} / \mathrm{ml})$

Figure. Effect of 2-deoxy-2,3-dehydro-N-acetylneuraminidase acid, on NA activity of $B$. fragilis BE 61 . Values are the mean and SD of three experiments.

\section{Discussion}

Colonisation of an epithelial surface is a complex process in which adherence is the first step. The affinity of a micro-organism for an epithelial surface is 
determined by the outcome of the interaction of the complex mixture of specific and non-specific factors that operate in situ. Factors such as the physical barrier of the mucus gel, the electrostatic repulsion between bacterial and epithelial cell surfaces, and competition by receptor analogues in mucosal secretion all interact at mucosal surfaces. It can be argued that the use of RBC and a transformed tissue culture cell line to measure adherence in relation to mucosal surfaces is artificial. However, mammalian cell lines in vitro give a relatively uniform population of cells that can be infected under defined conditions. This enables selective modification of either the infective agent or the host cell to be measured.

In the present investigation, the role of NA on HA and adherence of $B$. fragilis strains was studied primarily. Strains of Pr. intermedia and P. gingivalis were also included because NA-dependent HA and adherence have been reported for Pr. intermedia. ${ }^{9} \mathrm{We}$ preferred to use colon WiDr cells rather than buccal epithelial cells and small intestine cells (I407) because $B$. fragilis is a normal inhabitant of the colon. Treatment of RBC or $B$. fragilis with NA resulted in a very small increase of HA (two-fold) in some of the strains but NA-inhibitor had no effect. The possibility that NA-inhibitor could not act on NA of $B$. fragilis was ruled out by demonstrating that the NA-inhibitor, at concentrations used for HA and adherence studies,

\section{References}

1. Finegold SM, George WC, Mulligan ME. Anaerobic infections. Chicago, Year Book Medical Publisher. 1986

2. MacLaren DM, Namavar F, Verweij-van Vught AMJJ, Vel WAC, Kaan JA. Pathogenic synergy: mixed intraabdominal infection. Antoine van Leeuwenhoek 1984; 50: 775-787.

3. Rotstein OD, Pruett L, Simmons RL. Mechanisms of microbial synergy in polymicrobial surgical infections. Rev Infect Dis $1985 ; 7: 151-170$.

4. Riley TV, Mee BJ. Neuraminidase production by Bacteroides species. FEMS Microbiol Lett 1984; 25: 229-232.

5. Inglis G, Bird GWG, Mitchell AAB, Milne GR, Wingham J. Effect of Bacteroides fragilis on the human erythrocyte membrane: pathogenesis of TK polyagglutination. $J$ Clin Pathol 1975; 28: 964-968.

6. Müller HE, Werner $H$. In vitro-Untersuchungen über das Vorommen von Neuraminidase bei Bacteroides-Arten. Pathol Microbiol 1970; 36: 135-152.

7. Fraser AG, Brown R. Neuraminidase production by Bacteroidaceae. J Med Microbiol 1981; 14: 63-76.

8. Uhlenbruk G, Pardoe GI, Bird GWG. On the specificity of lectins with a broad agglutination spectrum. II. Studies on inhibited NA activity of $B$. fragilis BE 61 by $85 \%$. Guzman et al. ${ }^{10}$ found that pre-treatment of RBC with NA increased the ability of $B$. fragilis to adhere to $\mathrm{RBC}$, oral epithelial cells and intestinal cells. However, they did not report the titre of NA-mediated HA and made no attempt to investigate whether NA-mediated $\mathrm{HA}$ and adherence to intestinal cells could be inhibited by NA-inhibitor. Further evidence that points to $B$. fragilis $\mathrm{HA}$ being independent of NA was the fact that no correlation was found between HA and NA activity. Adherence of $B$. fragilis strains to WiDr cells was not mediated by NA nor was it affected by inhibition of NA. The absence of a relationship between HA and adherence of bacterial strains to WiDr cells agrees with the findings of Oyston and Handley, ${ }^{14}$ who used HT-29 colon cells. However, our finding that NA had no noticeable effect (only a twofold increase) on the HA activity of the Pr. intermedia and $P$. gingivalis strains tested contrasts with the work by Okuda et al. ${ }^{9}$ Moreover, Pr. intermedia HG 110 , which was also investigated by Okuda et al..$^{9}$ showed NA-mediated HA, and was auto-agglutinable in our hands, thus effectively rendering adherence assays with WiDr cells impossible. NA-dependent HA of autoagglutinable strains is an interesting observation which merits further investigation. However, our results indicate that HA and adherence to WiDr cells by $B$. fragilis are not mediated by NA.

the nature of the T-antigen and the specific receptors for the lectin of Arachis hypogoea (ground nut). Z Immun Forsch $1969 ; 138$ : 423-433.

9. Okuda K, Ono M, Kato T. Neuraminidase-enhanced attachment of Bacteroides intermedius to human erythrocyte and buccal epithelial cells. Infect Immun 1989; 57: 1635-1637.

10. Guzmán CA, Platé M, Pruzzo C. Role of neuraminidasedependent adherence in Bacteroides fragilis attachment to human epithelial cells. FEMS Microbiol Lett 1990; 71 : 187-192.

11. Namavar F, Verweij-van Vught AMJJ, MacLaren DM. A study of the candidate virulence factor of Bacteroides fragilis. J Gen Microbiol 1991; 137: 1431-1435.

12. Shah HN, Williams RAD, Bowden GH, Hardie JM. Comparison of the biochemical properties of Bacteroides melaninogenicus for human dental plaque and other sites. $J$ Appl Bacteriol 1976; 41 : 473-495.

13. Costello AH, Cisar JO, Kolenbrander PE, Gabriel O. Neuraminidase-dependent haemagglutination of human erythrocytes by human strains of Actinomyces viscosus and Actinomyces naeslundii. Infect Immun 1979; 26: 563-572.

14. Oyston PCF, Handley PS. Surface components of Bacteroides fragilis involved in adhesion and haemagglutination. $J \mathbf{M e d}$ Microbiol 1991; 34: 51-55. 